\title{
ISSUES AND CHALLENGES OF FINANCIAL MANAGEMENT PRACTICES IN ISLAMIC FINANCIAL INSTITUTIONS: EMPIRICAL EVIDENCE FROM BANGLADESH
}

\author{
Serajul Islam \\ Associate Professor \\ Department of Business Administration \\ International Islamic University Chittagong, Chittagong, Bangladesh \\ E-mail: serajulislamiiuc@ gmail.com \\ Dr. Abdullahil Mamun \\ Associate Professor \\ Department of Business Administration \\ International Islamic University Chittagong, Chittagong, Bangladesh \\ Research Fellow, YTB, Turkey \\ E-mail: ahm.economics@gmail.com \\ K. M. Anwarul Islam \\ Associate Professor \\ Department of Business Administration \\ The Millennium University, Dhaka, Bangladesh \\ PhD Candidate \\ University of Selangor, Malaysia (USM) \\ E-mail: ai419bankingdu@gmail.com

\section{Dr. Mohammad Rahim Uddin} \\ Assistant Professor \\ Department of Business Administration \\ International Islamic University Chittagong, Chittagong, Bangladesh \\ E-mail: mructg@gmail.com \\ Tania Sultana \\ Lecturer \\ Department of Business Administration \\ International Islamic University Chittagong, Chittagong, Bangladesh \\ E-mail: taniasultanaiiuc@gmail.com
}

\begin{abstract}
Studies suggest several issues and challenges of financial management practices in Islamic banks and insurance companies and Islamic non-bank financial institutions (INBFIs) in Bangladesh. The purpose of the research is to examine the issues and challenges of Islamic
\end{abstract}


Financial Management (IFM) from an empirical perspective. The study relies on a structured questionnaire survey in prominent Islamic financial institutions (IFIs) of Bangladesh for achieving its objective. After confirming data reliability based on Cronbach's alpha, the study proceeds to analyse by applying descriptive statistics and principal component factor analysis using correlation, Kaiser-Meyer-Olkin (KMO) and Bartlett's Test and VARIMAX Rotation. The study finds that there is no separate regulatory framework to supervise and monitor IFIs in Bangladesh rather the central bank regulates the Islamic financial system based on the existing laws and regulations of the conventional financial system. The findings of this study suggest that the government should establish a separate regulatory body for monitoring the IFI's functions so that they can perform their activities smoothly in the congenial environment in Bangladesh.

Keywords: Islamic Finance, Shariah Compliance, Bangladesh.

JEL Classification Codes: G10, G21, G23.

\section{INTRODUCTION}

The Islamic Financial Management (IFM) is the application of Shariah (Islamic law) to banking, insurance, and non-bank financial institutions (Khan, 2007). Sharing risk and reward between borrowers and lenders is the main principle of Islamic Finance (Divanna, 2009). Hence, the pursuance of Shariah principles in banking and insurance practices is expected to promote justice and equity confirming efficiency in resource allocation and income distribution and guarding the debt creation through direct borrowing and lending. Moreover, the Islamic banking system includes a strict framework of sharing risk by the financier for the financial system (Ahmed, 2010). As the banking system is changing with time, the Islamic financial system is also introducing innovative ideas to come across the changing desires of customers and businesses (Aziz, 2006).

While the advocates of Islamic Banking and Finance (IBF) claim its superiority because of the fairness in the distribution of risk and return, the opponents criticise the system and its products to be riskier relative to its conventional counterpart. Providing justice and honesty to both the parties in all financial transactions is the aim of IBF (Abu-Tapanjeh, 2009). In contrast, Fiennes (2007) pointed out that Islamic banks have features similar to conventional banks that include, market risk, investment risk, and business risks. The high riskiness of Islamic banking products and services is confirmed by the findings of Sundararajan and Errico (2002). Khan and Ahmed (2001) find that risks borne by Islamic banks are similar to conventional banks in nature due to a picky arrangement of their financial statements though they have different principles.

Ather (2007) highlighted some of the crucial issues faced by the IBF industry and IFM in particular. These issues are mainly associated with managerial activities, planning, organizing, motivation, controlling, and legal issues from an Islamic perspective. IBF faces challenges concerning institutional and operational aspects (Iqbal, Ahmad, \& Khan, 1998). But no empirical research has been performed addressing the issues and challenges the authors' pointed out for the case of Bangladesh. Since the Islamic financial industry of Bangladesh is growing markedly, the empirical investigation on the issues and challenges of IFM practices faced by Islamic banks, Islamic insurance companies and INBFIs in Bangladesh is the demand of time to help policymakers to take policies inappropriate directions. The study is an effort to this end. Moreover, management practices of IFIs in Bangladesh are abstruse among the commons and the study is an attempt to clarify their misconceptions. 


\section{LITERATURE REVIEW}

Financial Management, in general, refers to the managerial activity which is concerned with planning and controlling the firm's financial resources (Pandey \& Ongpipattanakul, 2015). Many factors like financial attitude, parental financial socialization, and financial literacy have a significant and positive relationship with prudent financial management practices (Bakar \& Bakar, 2020). It is concerned with the duties of the financial managers in the firm. It focuses on capital budgeting, capital structure, and working capital management for maximizing its value.

In contrast to the conventional management practices, the definition of IFM significantly varies with the former. However, for a better understanding of IFM from the Shariah perspective, it is indeed necessary to have an idea of what is IBF and how they operate their business. Divanna (2009) defined Islamic finance as the application of Shariah in banking. Parties, the banking institutions, and their client share profit and loss in Islamic finance. Moreover, Islamic law does not allow transactions based on interest (Riba) as it is an unjust means of financing from an Islamic perspective. Mohammed (2005) mentioned that Shariah neither allows interestbased business nor the making money nor cheers from the barter system of transaction. Islamic finance encourages all to share the profit or loss of the investment. Islam requires both the financier and the entrepreneur to equitably share the profit as well as the loss to fulfill the condition of justice. Hence, under Islamic finance, no one can gain profit without taking the risk. That is why strict discipline is maintained for assessing the risks and monitoring the funds using effectively by the fund users. The fund provider and borrower both the parties are concerned about assessing and reducing risks.

Islamic banks engage in banking activities based on the various Islamic financial contracts available. Mudarabah mode is used to mobilize funds in the deposit transactions (Qard Al Hasan). Kahf and Khan (1992) pointed out that the rate of return cannot be fixed under Islamic finance. So, Mudarabah is a financing mode and Musharakah is an investment mode. Salman and Nawaz (2018) argued that there is no huge difference between a banking system from an Islamic perspective and a conventional banking system in terms of banking services.

Bakkeri \& Ali (2020) examine the impact of internal and external factors on the profitability of 30 Islamic banks operating in the Middle East and North Africa over a period from 2005 till 2018 applying the OLS Panel data analysis technique and identify that quality of management has significance control on the banks' profitability.

Aziz (2006) argued that IFM is playing a vital role to meet the requirements of businesses in the changing arena. It is a new internationally integrated system for satisfying the current needs of clients in the age of globalization and liberalization. Financial management is also serving in a competitive modern age and a changing environment. Treating the profit-sharing investment schemes in a way consistent with financial stability is one of the most important regulatory challenges faced by IFIs (Kammer, et al., 2015; Mamun, et al., 2017).

Banning risk sharing, Islamic finance is very efficient and effective in handling the global financial crisis. In contrast to the debilitation of major financial institutions in the USA and Europe following the global financial crisis, IFIs were able to repel shocks owing to the distinctive Islamic financial framework (Haseeb, 2018). As Hasan (2015) argued, the cause of the global financial crisis in 2007-2008 was due to the reliance on an interest-based traditional financial system that completely relies on the transfer of risks. However, Islamic finance replaces the convention practices by prohibiting interest and promoting risk-sharing, and thereby ensures a financial system that is fair, firm and free from crisis. 


\section{Data and Sample}

\section{DATA AND METHODOLOGY}

The study has conducted a questionnaire survey using a direct interview method at the capital city Dhaka and Chittagong, the commercial capital of Bangladesh, respectively. The study relies on the direct interview method to reduce the non-response rate and to help to derive conclusions regarding respondents' inference and attitudes. The study has covered some selected organizations practicing IFM in Bangladesh. The sample contains eight full-fledged Islamic banks, six takaful (Islamic insurance) companies, and two INBFIs to conduct the study. To determine the sample size, a similar approach to Islam (2005) is followed in this study. The questionnaire survey of the study conducted an initial target of 500 samples; however, the study observed that only 380 samples can be used after the statistical screening. The overall achievement of collecting survey data was $76 \%$ and this is considered relatively fair in the field (Ahmed, 2009). So we consider the dataset being sufficient to have a representative sample that would allow the study to form policy prescriptions based on the findings.

Because of the limited resources, all the branches of the sample were not included in the survey. Based on the convention, it was agreed to survey only 2 branches from each of the sample banks, insurance companies, and INBFIs. While choosing the branch, several other criteria were also taken into consideration, such as their size (large, medium, and small) based on the number of employees, customers, operating income, etc.

Purposive sampling was chosen to interview the sample respondents. Purposive sampling logically pretend to be responsive to the population using expert knowledge in a non-random manner that represents a cross-section of the population (Lavrakas, 2008)

A list of clients has been collected from all selected branches through the bank administration. Then, two clients from each selected branch are picked following a simple random sampling method. The stated method has been chosen because each member of a population has the same chance of being included in the sample and where all possible samples of a given size have the same chance of selection as directed by West (2016).

From each of the branch, a branch manager and a senior level officer surveyed data have been used in the study. So, in total, 65 for specific Islamic banking (14 top officials and 51 investors), 40 for Takaful (10 top officials and 30 investors), 20 for Islamic Capital market (officials), and 255 for overall IFM practices in Bangladesh. Out of 255 samples, top officials are 64, other officers 80, investors (clients) 64, and academicians 47. However, to respect the respondents and maintain unanimity, their identities are not revealed in the study.

\section{Instrument Design}

Based on the literature review, a questionnaire was prepared in consultation with a few selected finance and management professors of different universities, prominent academicians, researchers and bankers. After getting the advice and suggestions from the experts, the questionnaire was finalized. To identify the key issues and challenges for IFM practices in Bangladesh, the structured questionnaire was developed based on a five-point Likert scale ranging from 1 (poor) to 5 (excellent). The relevance and validity of the questionnaire are tested by performing a pilot survey before its final use. The study maintained strict confidentiality of the respondents and proper procedures are followed to collect the data.

The questionnaire has two parts, part-A, and part-B. Part-A consists of basic demographic variables, such as identity, position, name of the organization, job experience, educational qualification, professional education, Islamic finance training or experience, and age 
of the respondents. Part-B includes 29 questions regarding practices of IFM, compliance with different laws, rules, regulations, and standards and challenges of practicing IFM, and suggestions for overcoming the challenges. Notably, the study uses three different types of questionnaires targeting different industries. For example, for Islamic banks and insurance companies, the study uses two different sets of questionnaires as the operational dynamic varies between the banks and insurance. Then, the study also prepares an overall questionnaire for the remaining respondent categories.

\section{Statistical Techniques}

Cronbach's alpha has been used to measure the data reliability. Cronbach's alpha is related to the variation accounted with the score of the underlying construct. Cronbach's alpha value that ranges between 0 to 1 describes the reliability (Hatcher, 1994). Alfa value 0.7 or more is highly acceptable but lower thresholds are also sometimes acceptable depending on the nature of data and population (Nunnaly, 1978).

Apart from that, correlation matrix, principal component analysis (PCA) using KaiserMeyer-Olkin (KMO) Bartlett's Test and VARIMAX Rotation have applied to analyse the data. It focuses to simplify the diver's connection from the existing commonplace of experimental variables by finding general magnitudes or aspects that connect jointly the dissimilar variables and thus presents approaching into the fundamental configurations of the facts (Dillon \& Goldstein, 1984). The Important dual uses of factor analysis are facts lessening and core elucidation. Though there are different versions/types of factor analyses available, in this research, 'PCVRM' (Principle Components VARIMAX Rotated Method) used in this study for identifying the factors that influence cost planning, cost controlling, cost efficiency and constraints to cost management practices of sample banks of Bangladesh. Since the techniques used in the study are well established in the literature, their discussion is not further extended in the analysis. Finally, regression technique has been used to rank the factors based on the scores derived.

\section{Demographic Design}

\section{DATA ANALYSIS AND DISCUSSION}

The age of the respondents in the study varied from 25 years to above 55 years. Maximum (28.68\%) of the respondents having the age of 30-35 years, $17.89 \%$ of them fall in the age range of $40-45$ years, $15.26 \%$ of them in the age category of $25-30$ years and $14.74 \%$ of them are in the age of $45-50$ years. Further, only $7.37 \%$ of the respondents having an age of more than 50 years. More specifically $39.77 \%$ of the top officials are in the age of $40-45$ years; $34.04 \%$ of the academicians are in the age of 30-35 years; $32 \%$ of the other officials and $40 \%$ of the investors are in the age of 30-35 years.

\section{Reliability Testing}

The results of the study show that the Cronbach's Alpha coefficient is 0.69 and Cronbach's Alpha based on standardized items coefficient is 0.78 . Hence, the primary data have been used by the researcher in the study is found to be reliable and consistent based on the conventional threshold.

This study has projected the 'Zero-Order Correlation Matrix' of 28items. From the perusal of the zero-order correlation matrix, it is found that some items have relatively strong correlations among them which are the main basis or justification to create a group or factor. In this study, it is found that some variables have emerged as the most significant factors which 
ultimately from different orthogonal factors.

\section{Challenges of Islamic Banks}

This section of the study presents the result of an opinion survey of 65 respondents from Islamic banks' personnel and clients to identify the issues and challenges faced by the Islamic banks in Bangladesh. Factors having the mean value greater than 4 are the most challenging factors; followed by factors having a value greater than 3.5 but less than 4 are the moderate challenging factors and factors for which the mean value falls short of 3.5 are the less challenging factors. Among the 28 challenging factors, 11 are the most challenging, 16 found as moderate challenging and only 1 is less challenging factors (table 1). The study found that the disparity in theory and practice especially in the case of risk-sharing instruments is the most challenging factor and Islamic financial markets offer a wide array of instruments with varying structures of maturity and opportunities for portfolio diversification and risk management is the less challenging factors.

The KMO measure shows that the sampling adequacy is 0.486 and Bartlett's test sphericity result is significant at $1 \%$ therefore, shows that the 28 challenging factors hold a minimum standard (eigenvalues greater than 1) to proceed for PCA. The result means that the whole variance accumulated to by the most challenging factor is $74.35 \%$ (11 factors) and seventeen factors explain the rest of the variance which includes sixteen moderate challenging factors and one less challenging factor.

Among the most challenging factors, the disparity in theory and practice especially in the case of risk-sharing instruments alone explains $16.31 \%$ of the variation. Moreover, for the moderate challenging factors the highest variation $3.37 \%$ belongs to the shortage of legal support of the Central bank in Bangladesh and sixteen moderate challenging factors to explain $25.32 \%$ of the total variation. Additionally, the less challenging factor, Islamic financial markets tender a large range of mechanisms with changeable compositions of maturity and chances for group diversification and management of risk explains $0.33 \%$ of the variation.

Table 1. Challenges of Islamic Banks in Bangladesh $(n=65)$

\begin{tabular}{|l|r|r|}
\hline \multicolumn{1}{|c|}{ Most Challenging Factors } & Mean & Std. Dev \\
\hline $\begin{array}{l}\text { The disparity in theory and practice especially in the case of risk-sharing } \\
\text { instruments }\end{array}$ & 4.2000 & .81394 \\
\hline Scarcity of qualified Shari'a scholars in different sectors & 4.1538 & .83349 \\
\hline Small assets and capital size & 4.1385 & 5.13529 \\
\hline Lack of Islamic interbank market & 4.1231 & .76050 \\
\hline Lack of Unified Shariah Rulings & 4.1077 & .77304 \\
\hline No Course on Islamic finance and banking in the education system & 4.0923 & .82392 \\
\hline Lack of debt and derivative markets & 4.0462 & .95902 \\
\hline Lack of appropriate legal framework and supportive policies & 4.0308 & .82858 \\
\hline Economic decelerate and political condition & 4.0308 & .93490 \\
\hline Diversity of the opinions of the Shariah scholars on various products & 4.0154 & .73935 \\
\hline $\begin{array}{l}\text { The central bank has no sufficient Shariah experts to control the functions of } \\
\text { IFIs }\end{array}$ & 4.0154 & .97616 \\
\hline \multicolumn{1}{|c|}{ Moderate Challenging Factors } & Mean & Std. Dev \\
\hline Shortage of legal support of the Central bank in Bangladesh & 3.9846 & .92690 \\
\hline
\end{tabular}




\begin{tabular}{|l|r|r|}
\hline $\begin{array}{l}\text { Providing predetermined return structures (Ijarah, Murabahah, etc.) rather } \\
\text { than profit-sharing scheme }\end{array}$ & 3.9692 & 1.03031 \\
\hline $\begin{array}{l}\text { Insufficient risk measures and diversification is the problem for Islamic } \\
\text { Financial Market }\end{array}$ & 3.9687 & .87230 \\
\hline Lack of Specialized Islamic Banks and NBFIs & 3.9538 & .90882 \\
\hline $\begin{array}{l}\text { Lack of well-functioning secondary markets and liquidity-enhancing and } \\
\text { risk-sharing products }\end{array}$ & 3.9077 & .97984 \\
\hline Lack of Apex Training Institute for the Islamic Banks & 3.8923 & .83147 \\
\hline $\begin{array}{l}\text { With increased globalization, integration and linkages have become critical } \\
\text { to the success of any capital market }\end{array}$ & 3.8615 & 1.01361 \\
\hline Lack of modern banking services & 3.8308 & 1.03937 \\
\hline No active enterprise-level risk management & 3.7692 & .98058 \\
\hline Lack of Shariah-based money market & 3.7385 & 1.06473 \\
\hline Lack of financial engineering and innovations & 3.7231 & .92715 \\
\hline Lack of an effective supervisory framework & 3.7077 & 1.02657 \\
\hline New Banking Regulations & 3.6769 & .83118 \\
\hline $\begin{array}{l}\text { Absence of internationally recognized legal, regulatory, and supervisory } \\
\text { framework for Islamic banking and financial management } \\
\text { There is yet no internationally generally accepted legal, regulatory, and } \\
\text { supervisory framework dealing with Islamic banking and financial } \\
\text { management }\end{array}$ & 3.6615 & 1.01976 \\
\hline Lack of congenial environment and strong non-banking financial supports & 3.6308 & .99325 \\
\hline $\begin{array}{l}\text { Insufficient investment for infrastructure development of the Islamic capital } \\
\text { market }\end{array}$ & 3.6190 & 1.00689 \\
\hline \multicolumn{1}{|c|}{ Lack of standard Islamic financial instruments } & 3.3077 & .93413 \\
\hline
\end{tabular}

Source: Author' Calculation

Issues and Challenges of Islamic Insurance Companies

This section of the study presents the result of an opinion that aims to find out the issues and challenges faced by the takaful industry in Bangladesh. Factors' having the value of the mean of greater than 4 is the most challenging factors; followed by factors having a mean of greater than 3.5 but less than 4 are the moderate challenging factors and factors having a mean of lower than 3.5 are the less challenging factors. Out of 19 challenging factors, 5 factors are the most challenging, 10 of them are moderate challenging and the rest of them (4) are less challenging factors (Table 2).

Table 2. Challenges of Islamic Insurance Companies $(n=80)$

\begin{tabular}{|l|r|r|}
\hline Most Challenging Factors & Mean & Std. Deviation \\
\hline Technological backwardness & 4.25 & 0.99 \\
\hline Shortage of suitable assets & 4.18 & 0.96 \\
\hline Too much stress on profit distribution & 4.04 & 0.98 \\
\hline Low income of the people & 4.03 & 3.66 \\
\hline Lack of standardization in the industry that is due to Shariah & 4.02 & 0.91 \\
\hline
\end{tabular}




\begin{tabular}{|l|r|r|}
\hline interpretations & Mean & Std. Deviation \\
\hline Moderate Challenging Factors & 3.87 & 2.28 \\
\hline Lack of product diversification & 3.75 & 1.23 \\
\hline Issue around retakaful & 3.75 & 1.01 \\
\hline Misguided by insurance official & 3.74 & 1.01 \\
\hline Lack of separate regulatory body & 3.70 & 1.11 \\
\hline High service cost & 3.57 & 1.15 \\
\hline Lack of attractive offerings & 3.52 & 1.30 \\
\hline Lack of quality controlling process & 3.36 & 1.28 \\
\hline Diverging regulatory approaches and the lack of centralized & & 1.33 \\
\hline regulations & 3.34 & 1.38 \\
\hline Riba & 3.32 & Mean \\
\hline Lack of government patronizing & 3.07 & Std. Deviation \\
\hline Less Challenging Factors & 3.04 & 1.44 \\
\hline Lack of marketing research & 2.97 & 1.31 \\
\hline Lack of efficient management & 2.79 & 1.40 \\
\hline Political instability & & 1.47 \\
\hline Lack of trustworthiness & & \\
\hline
\end{tabular}

\section{Source: Authors' calculation}

\section{PCA of Challenges of Islamic Insurance Companies}

PCA has been applied to analyse the challenges of Islamic Insurance Companies. The result of the analysis discovers that KMO (Kaiser-Meyer-Olkin) and Bartlett's test measurement result of challenges of Takaful industry in Bangladesh. The acceptance KMO value should be larger than 0.5. Field (2000); and Pallant (2013) argued that the value should be 0.60 or above. The KMO measure shows that the sampling adequacy is 0.711 and Bartlett's test sphericity result is significant at $1 \%$ therefore, shows that the 19 challenging factors hold a minimum standard to proceed for PCA (Table 3).

There are five most significant issues (technological backwardness, shortage of suitable assets, Too much stress on profit distribution, low income of the people and short of standardization), ten significant issues (lack of product diversification, issue around retakaful, misguided by insurance official, lack of separate regulatory body, high service cost, lack of attractive offerings, lack of quality controlling process, deviating dogmatic approaches and short of centralized rules, riba and lack of government patronizing) and four less significant issues (lack of marketing research, lack of efficient management, political instability and lack of trustworthiness). Moreover, table 10 shows that the highest variation is $5.42 \%$ for moderate challenging factors by the lack of product diversification and the total variation explained by the ten moderate challenging factors is $39.37 \%$. Additionally, among the less challenging factors, the highest variation is $2.45 \%$ that goes to lack of marketing research and the total variation explained by the four moderate challenging factors is $8.84 \%$. 
Table 3. Total Variance Explained for Challenges of Islamic Insurance Companies

\begin{tabular}{|c|c|c|c|c|c|c|c|}
\hline Challenging & \multicolumn{3}{|c|}{ Eigenvalues } & Challenging & \multicolumn{3}{|c|}{ Eigenvalues } \\
\cline { 3 - 4 } \cline { 6 - 7 } Factors & Total & $\begin{array}{c}\text { \% of } \\
\text { Variance }\end{array}$ & $\begin{array}{c}\text { Cumulative } \\
\text { \% }\end{array}$ & Factors & Total & $\begin{array}{c}\text { \% of } \\
\text { Variance }\end{array}$ & $\begin{array}{c}\text { Cumulative } \\
\text { \% }\end{array}$ \\
\hline 1 & 3.10 & 16.31 & 16.31 & 11 & 0.69 & 3.61 & 78.82 \\
\hline 2 & 2.42 & 12.73 & 29.04 & 12 & 0.64 & 3.36 & 82.17 \\
\hline 3 & 1.83 & 9.61 & 38.65 & 13 & 0.60 & 3.15 & 85.33 \\
\hline 4 & 1.42 & 7.46 & 46.10 & 14 & 0.58 & 3.03 & 88.36 \\
\hline 5 & 1.08 & 5.70 & 51.80 & 15 & 0.53 & 2.81 & 91.17 \\
\hline 6 & 1.03 & 5.42 & 57.22 & 16 & 0.47 & 2.45 & 93.61 \\
\hline 7 & 0.95 & 5.00 & 62.22 & 17 & 0.46 & 2.44 & 96.05 \\
\hline 8 & 0.91 & 4.81 & 67.03 & 18 & 0.41 & 2.13 & 98.18 \\
\hline 9 & 0.84 & 4.42 & 71.45 & 19 & 0.35 & 1.82 & 100.00 \\
\hline 10 & 0.72 & 3.76 & 75.21 & & & & \\
\hline
\end{tabular}

Source: Authors' calculation

\section{i. Technological Backwardness}

Islamic insurance companies in Bangladesh are using traditional methods for insurance policies whereas some of the conventional insurance companies are following modern systems as computerized systems in their operations (Khan et al., 2016), The clients of Islamic insurance companies are deprived of the convenient use of e-insurance, online business, internet, and computerized system. As a result, the customers are vague in some facts such as payment of premium, claim settlement and balance of policy holder's account. Bashir and Mail (2011) mentioned that Islamic insurance companies need to be technologically sound and updated in providing their services. This study found that technological backwardness is one of the most significant issues for Islamic insurance companies in Bangladesh.

\section{ii. Lack of Shariah-based assets}

Lack of Shariah-based assets hampers the fastest growth of the Islamic financial market. The lack of suitable Shariah-compliant, limited range of Shariah-compliant, asset-liability management, and the cost of maintaining Shariah-compliant are some of the challenges for the Islamic insurance companies (Jaffer et al., 2010). In this study, 85\% of the respondents mentioned there is a lack of Shariah-compliant assets. It is also one of the most significant issues for the Islamic insurance industry.

\section{iii. Too much stress on profit distribution}

The profit motive is the main concern of the conventional insurance companies; they provide generally more profit to the clients than the Islamic insurance companies. It presses too much stress on profit distribution that hampers the social corporate responsibilities (CSR) activities. It is one of the major issues of Islamic insurance companies (Maghrebi \& Mirakhor, 2015).

\section{iv. Low income of the people}

Bangladesh low-income country and many people live in extreme poverty (Hossain, 2014). Poor people of Bangladesh are working hard to earn their livelihood and are marginalized with to the expenditure with the income. Thus, their propensity to save is very small. It is often difficult for them to save some money for future needs (Sheheli, 2012). Therefore, the overall poor economic 
condition is creating an obstacle to flourishing the Islamic insurance business in Bangladesh.

\section{v. Shortage of standardization from an Islamic perspective}

Despite the Islamic insurance expanding rapidly, there are still some issues currently being debated among Shariah scholars and Muslim jurists (Maghrebi \& Mirakhor, 2015; Fauzi et al., 2016). The contradictions of Shariah explanations can be viewed in the aspects: wa'd (promise), underwriting surplus, choice of takaful models, sources of capital, the type of risk deemed acceptable in Takaful, Wakala fees and the cost of capital (Isa et al., 2017; Akhter, 2010). In this study, $70 \%$ of respondents have argued that it has a negative impact on the smooth operation of the takaful industry.

\section{vi. Riba}

Although the takaful practices are free from the elements of Riba in Bangladesh, their activities and products are limited to a few numbers of investors and a narrow area (Sarwar, 2016). According to Htay and Salman (2013); Saleh (2016); and Sarwar (2016), the takaful practices are evolved around the elements of Mudarabah, Tabarru and other Shariah justified elements. In this study, some of the respondents raised their voices that it is difficult to convince general investors and clients that they are interest-free a like the traditional insurance system. Partly it is true because the money that a client pays is similar to the premium being charged in the conventional insurance industry.

\section{vii. Issues surrounding Retakaful}

There is a lack of capacity within the takaful industry for reinsurance. Therefore, a certain proportion of risk is placed with the international reinsurance companies that operate on a conventional basis (Rahman, Ahmad \& Buang, 2011). The study found that some of the respondents admitted that it is a great problem for the industry.

\section{viii. Lengthy procedure in Claim's settlement}

According to Khan et al. (2016), the claim settlement in Bangladesh is a lengthy and timeconsuming procedure. In this study, many respondents agreed that the lengthy procedure in claim settlement hampers the goodwill of the industry.

\section{ix. Shortage of skilled personnel}

Skilled human resources are one of the major keys to gain success. Many countries where financial management is administered by Islamic Shariah are getting success by utilizing skilled personnel. The leading insurance companies in KSA emerged as the leader of the market in terms of managerial efficiency, and could be benchmarked by other companies operated in the market (Naushad, Faridi, \& Faisal, 2020). One of the major challenges faced by the Islamic insurance companies in Bangladesh and many other countries is the lack of knowledgeable and qualified personnel. Most of the companies typically employ human resources having a conventional educational background with traditional experiences. These personnel usually try to implement their conventional insurance experiences to the Islamic insurance companies that occasionally hamper the smooth takaful operations (Khan et al., 2016; Ochieng, 2013). This has been certified from the findings of the study that qualified personnel are scarce in takaful industry in Bangladesh. 


\section{x. Lack of Regulatory and Legal Framework}

Traditional insurance companies in Bangladesh are suffering from many customer faces hidden charges, extra fees, account hacked (Rahman, 2018). Shariah-based insurance companies also suffering here either on the same ground as traditional companies or from the different grounds. Since there is no standardization of the takaful authoritarian system globally, only the Shariah board of respective Islamic insurance companies guides all the activities by maintaining its regulatory constraints (Jaffer et al., 2010). In Bangladesh, there is no specific legal framework for the takaful industry as highlighted in the earlier chapters. Islamic insurance operates under a conventional legal framework (Sarwar, 2016). This study also found that some of the respondents acknowledge that lack of regulatory and legal framework is a major obstacle for the takaful industry in Bangladesh.

\section{ANALYSIS OF FACTORS OF CHALLENGES OF IFM PRACTICES}

The Factor-I explains $25.33 \%$ variations of the set. It includes the following items; difficulties in attracting investors (DAI), weak regulation for capital budgeting (WRFCB), dual operation (DO), the influence of risk-free rate (IRFR), shortage of experts in IFM (SE), lack of Sukuk market (LSM), consideration of whole market risk (CWMR), no benefit of tax shield (NBTS), opportunity cost (OC), WACC and PBP (Table 4).

Factor II explains $36.24 \%$ variations in the variables. The variables are: not following IFM (NFIFM), dependence on debt-based financing (DDF), partial using of financing instruments (PUFI), avoiding Musharka financing (AMF), lack of innovation (LI), absence of Islamic Derivatives Market (AIDM), unclear terms and conditions (UTC) and absence of clarification (AC) (Table 4).

Factor III explains $23.42 \%$ variations in the variables. The variables are: lack of liquidity instruments (LLI), regulatory framework (RF), supervisory framework (SF), economic and political instability (EPI), insufficient risk measures and diversification (IRMD), crowding effect (CE), call money market (CMM), lack of secondary market (LSM) and accounting standard (AS) (Table 4).

Table 4. Factors Challenges IFM Practices

\begin{tabular}{|l|l|r|}
\hline \multicolumn{1}{|l|}{ Factors I-Capital Budgeting Challenges } & $\begin{array}{c}\text { Factor } \\
\text { Loading }\end{array}$ \\
\hline ID & \multicolumn{1}{|c|}{ Variables } & 0.971 \\
\hline HCC & $\begin{array}{l}\text { In calculating the cost of capital for capital budgeting risk-free rate } \\
\text { influences Islamic Capital Budgeting }\end{array}$ & 0.961 \\
\hline OC & Opportunity cost influences the capital budgeting decision of IFM. & 0.921 \\
\hline DAI & $\begin{array}{l}\text { IFI faced more difficulties in attracting lenders and borrowers than interest- } \\
\text { based institutions. }\end{array}$ & 0.977 \\
\hline SE & $\begin{array}{l}\text { Due to the shortage of Islamic Finance Expert, capital budgeting techniques } \\
\text { are not fully adopted in IFM. }\end{array}$ & 0.966 \\
\hline WRFCB & $\begin{array}{l}\text { As IFI is regulated by the conventional authority there are no specific laws } \\
\text { and regulations for Islamic Capital Budgeting. }\end{array}$ & 0.963 \\
\hline DO & $\begin{array}{l}\text { Due to dual operation with the conventional capital market, IFIs get the } \\
\text { narrow scope for capital budgeting. }\end{array}$ & 0.822 \\
\hline WACC & In calculating WACC, IFM prefers CAPM rather than DCF. & \\
\hline
\end{tabular}




\begin{tabular}{|c|c|c|}
\hline CWMR & $\begin{array}{l}\text { In calculating WACC for Islamic Capital Budgeting, IFM considers whole } \\
\text { market risk including conventional market. }\end{array}$ & 0.956 \\
\hline PBP & $\begin{array}{l}\text { Most of the Islamic Firms follow PBP for evaluating the capital budget } \\
\text { decision. }\end{array}$ & 0.958 \\
\hline IRFR & $\begin{array}{l}\text { In calculating the cost of capital for capital budgeting, risk-free rate } \\
\text { influences Islamic Capital Budgeting. }\end{array}$ & 0.938 \\
\hline NBTS & $\begin{array}{l}\text { Most of the Islamic Firms avoid debt financing in capital budgeting which } \\
\text { doesn't help them to avoid tax. }\end{array}$ & 0.738 \\
\hline LSM & $\begin{array}{l}\text { Due to the lack of the Sukuk market, debt-based financing is narrowly } \\
\text { followed by IFM. }\end{array}$ & 0.494 \\
\hline & Variance accounted for & $25.33 \%$ \\
\hline \multicolumn{3}{|c|}{ Factor II-Capital Structure Challenges } \\
\hline ID & Variables & $\begin{array}{l}\text { Factors } \\
\text { Loading }\end{array}$ \\
\hline NFIFM & Most of the institutions follow conventional methods for IFM. & 0.967 \\
\hline DDF & $\begin{array}{l}\text { In the capital structure of IFM, most of the firms prefer debt-based financing } \\
\text { rather than equity based. }\end{array}$ & 0.612 \\
\hline PUFI & $\begin{array}{l}\text { In fundraising Islamic Finance Institutions mostly rely on Mudarabah mode } \\
\text { rather than Musharakah. }\end{array}$ & 0.704 \\
\hline AMF & IFI avoid Musaharakah mode for financing due to distrusted people & 0.086 \\
\hline LI & Product innovation in Islamic Finance is narrowly adopted. & 0.043 \\
\hline AIDM & $\begin{array}{l}\text { The Absence of Islamic Derivatives Market IFI cannot reduce risk in } \\
\text { financing. }\end{array}$ & 0.289 \\
\hline UTC & $\begin{array}{l}\text { The procedure stream of the product is undefined and the parties are } \\
\text { unidentified. }\end{array}$ & 0.971 \\
\hline $\mathrm{AC}$ & $\begin{array}{l}\text { There are unclear profit distribution and untraced fund's flow on some of the } \\
\text { new products }\end{array}$ & 0.961 \\
\hline & Variance accounted for & $36.24 \%$ \\
\hline \multicolumn{3}{|c|}{ Factors III - Working Capital Management Challenges } \\
\hline ID & Variables & $\begin{array}{l}\text { Factors } \\
\text { Loading }\end{array}$ \\
\hline LLI & There is a lack of Shariah knowledge among the product developers & 0.921 \\
\hline $\mathrm{RF}$ & $\begin{array}{l}\text { Insufficient risk measures and diversification is the problem for Islamic } \\
\text { Financing Decision. }\end{array}$ & 0.977 \\
\hline SF & Lack of effective and efficient Islamic secondary markets & 0.967 \\
\hline EPI & $\begin{array}{l}\text { Lack of effective supervisory framework influences working capital } \\
\text { management. }\end{array}$ & 0.966 \\
\hline IRMD & $\begin{array}{l}\text { Economic decelerate and Political conditions influence working capital } \\
\text { management. }\end{array}$ & 0.963 \\
\hline CMM & $\begin{array}{l}\text { Due to the lack of full pledge Islamic Call Money Market, short-term } \\
\text { borrowings are not properly utilized. }\end{array}$ & 0.822 \\
\hline $\mathrm{CE}$ & $\begin{array}{l}\text { Most of the Islamic firms rely on IFI for short-term borrowing which creates } \\
\text { a crowding effect. }\end{array}$ & 0.956 \\
\hline AS & $\begin{array}{l}\text { Standard Islamic Accounting methods are not accurately defined to measure } \\
\text { working capital management. }\end{array}$ & 0.958 \\
\hline
\end{tabular}


Lack of Shariah Complaint emergency liquidity instruments. Variance accounted for

\section{Source: Authors' calculation}

\section{Overall Challenges of IFM in Bangladesh}

To provide the overall answer to the IFM practices of IFI in Bangladesh, the study used the opinions of 255 sample professionals on 5-point Likert VRFA ("VARIMAX Rotated Factor Analytical") technique was employed to group the selected variables based on their intrinsic connections and lastly grading the group based on their values. The study has identified the variables undertaken for the study as most significant to less significant based on their mean score of opinions taken of 5-point Likert Scale. The challenges influencing the IFM based on weighted scores are shown in Table 5.Challenges having more than 3.9 mean values have been identified as the most significant challenges and the challenges having a mean value ranges from 3.5 to 3.9 are significant challenges. The mean value of less than 3.5 is considered as less significant challenges. Based on Table 9, eight challenges having a mean score of more than 3.9 are identified as the most significant. Three are capital budgeting related, two are capital structure and three are working capital management related challenge.

Table 5. Descriptive Statistics of the Challenges Influencing the IFM $(n=255)$

\begin{tabular}{|l|c|c|}
\hline \multicolumn{1}{|c|}{ Variables } & Mean & Std. Dev \\
\hline $\begin{array}{l}\text { In calculating the cost of finance, Islamic Capital Budgeting uses } \mathrm{K}_{\mathrm{RFI}} \text { instead } \\
\text { of } \mathrm{K}_{\mathrm{RF}} \text {. Therefore, the cost of capital is higher than the conventional capital } \\
\text { budgeting which limits the investment avenues }\end{array}$ & 4.17 & 1.05 \\
\hline Lack of Shariah Complaint emergency liquidity instruments & 4.17 & 1.05 \\
\hline $\begin{array}{l}\text { IFI faces more difficulties in attracting investors (lenders and borrowers) than } \\
\text { interest-based institutions. }\end{array}$ & 4.15 & 0.96 \\
\hline $\begin{array}{l}\text { Regulators do not always have the capacity (or willingness) to ensure Shariah } \\
\text { compliance, which undermines consistency of approaches within and across } \\
\text { borders. }\end{array}$ & 4.15 & 0.96 \\
\hline Lack of specific laws and regulations for Islamic Capital Budgeting & 3.98 & 0.91 \\
\hline $\begin{array}{l}\text { Lack of effective supervisory framework influences working capital } \\
\text { management. }\end{array}$ & 3.98 & 0.91 \\
\hline $\begin{array}{l}\text { Due to dual operation with the conventional capital market, IFIs get a narrow } \\
\text { scope for capital budgeting. }\end{array}$ & 3.97 & 0.98 \\
\hline $\begin{array}{l}\text { Economic decelerate and political condition influence working capital } \\
\text { management. }\end{array}$ & 3.97 & 0.98 \\
\hline $\begin{array}{l}\text { In fundraising Islamic Finance Institutions mostly rely on Mudarabah mode } \\
\text { rather than Musharakah. }\end{array}$ & 3.85 & 3.35 \\
\hline $\begin{array}{l}\text { The Absence of Islamic Derivatives Market IFI cannot reduce risk in } \\
\text { financing. }\end{array}$ & 3.84 & 2.30 \\
\hline $\begin{array}{l}\text { In calculating the cost of capital for capital budgeting risk-free rate influences } \\
\text { in Islamic Capital Budgeting. }\end{array}$ & 3.80 & 1.27 \\
\hline $\begin{array}{l}\text { The procedure stream of the product is undefined and the parties are } \\
\text { unidentified. }\end{array}$ & 3.80 & 1.27 \\
\hline Due to the shortage of Islamic Finance Experts, capital budgeting techniques & 3.64 & 1.02 \\
\hline
\end{tabular}




\begin{tabular}{|l|c|c|}
\hline are not fully adopted in IFM. & \\
\hline $\begin{array}{l}\text { Insufficient risk measures and diversification is the problem for Islamic } \\
\text { Financing Decision. }\end{array}$ & 3.64 & 1.02 \\
\hline Lack of Sukuk market debt-based financing is narrowly followed by IFM. & 3.56 & 1.01 \\
\hline $\begin{array}{l}\text { In calculating WACC for Islamic Capital Budgeting, IFM considers whole } \\
\text { market risk including conventional market. }\end{array}$ & 3.54 & 1.13 \\
\hline $\begin{array}{l}\text { Most of the Islamic firms rely on IFI for short-term borrowing which creates a } \\
\text { crowding effect. }\end{array}$ & 3.54 & 1.13 \\
\hline $\begin{array}{l}\text { In the capital structure of IFM, most of the firms prefer debt-based financing } \\
\text { rather equity-based. }\end{array}$ & 3.53 & 1.15 \\
\hline $\begin{array}{l}\text { Most of the Islamic Firms avoid debt financing in capital budgeting which } \\
\text { doesn't help them to avoid tax. }\end{array}$ & 3.49 & 1.23 \\
\hline Product innovation in Islamic Finance is narrowly adopted. & 3.31 & 1.33 \\
\hline Opportunity cost influences the capital budgeting decision of IFM. & 3.25 & 1.27 \\
\hline $\begin{array}{l}\text { There are unclear profit distribution and untraced fund's flow on some of the } \\
\text { new products }\end{array}$ & 3.25 & 1.27 \\
\hline In calculating WACC IFM prefers CAPM rather DCF. & 3.17 & 1.28 \\
\hline $\begin{array}{l}\text { Due to the lack of full pledge of Islamic Call Money Market, short-term } \\
\text { borrowings are not properly utilized. }\end{array}$ & 3.17 & 1.28 \\
\hline Most of the institutions follow conventional methods for IFM. & 3.10 & 1.35 \\
\hline Lack of effective and efficient Islamic secondary markets & 3.10 & 1.35 \\
\hline $\begin{array}{l}\text { Due to uncertainty about getting proper information, Islamic Finance avoids } \\
\text { the Musaharakah mode of financing. }\end{array}$ & 2.86 & 2.29 \\
\hline $\begin{array}{l}\text { Most of the Islamic Firms follow PBP for evaluating the capital budget } \\
\text { decisions. }\end{array}$ & 2.48 & 1.39 \\
\hline $\begin{array}{l}\text { Standard Islamic Accounting methods are not accurately defined to measure } \\
\text { working capital management. }\end{array}$ & 2.48 & 1.39 \\
\hline
\end{tabular}

Source: Authors' calculation

\section{CONCLUSION}

In the aftermath of the global financial crisis, the government and the Bangladesh bank have actively supported Islamic finance. But the guidelines for the IBF need to be upgraded for their smooth functioning. Thus, the study helps to design a more comprehensive and consistent legal and regulatory framework for the Islamic financial services industry in Bangladesh. This will support the analysts and decision-makers to outline some contours of a roadmap for further development of the Islamic finance industry in Bangladesh.

In short, it is evident that there is no separate regulatory framework to supervise and monitor IFI in Bangladesh, rather the central bank (Bangladesh Bank) regulates the Islamic financial system based on the existing conventional financial system laws and regulations. Besides, Bangladesh bank provides some guidelines to establish a Shariah council for the Islamic financial system. Hence, the lack of a legal and regulatory framework has stifled the IBF industry in Bangladesh.

The study analyses financial management practices in IFIs of Bangladesh and found some conclusions based on findings. Although the financial management practices in IFIs of Bangladesh are endowed, there are several factors the hamper the normal activities of the industry. Therefore, it is very essential for the respective practitioners and policymakers for 
giving their wholehearted concentration on facing the challenges. In this connection, at first, the government should establish a separate regulatory body for monitoring the IFI's functions so that they can perform their activities smoothly in a congenial environment in Bangladesh.

\section{REFERENCES}

Abu-Tapanjeh, A. M. (2009). Corporate governance from the Islamic perspective: A comparative analysis with OECD principles, Critical Perspectives on accounting, 20(5), 556-567.

Ahmed, A. (2010). Global financial crisis: an Islamic finance perspective", International Journal of Islamic and Middle Eastern Finance and Management, 3(4), 306-320.

Ahmed, H. (2009). Financial crisis, risks and lessons for Islamic finance, ISRA International Journal of Islamic Finance, 1(1), 7-32.

Akhter, W. (2010). Takaful Models and Global Practices. Journal of Islamic banking and finance, 27(1), 30-44.

Ather, S. M. (2007). Islamic Management and Business, Noksha Publications, Chittagong.

Aziz, Z. A. (2006). Islamic Banking and Finance Progress and Prospects Collected Speeches: 2000-2006, Bank Negara Malaysia, Kuala Lumpur.

Bakar, M. Z. A., \& Bakar, S. A. (2020). Prudent Financial Management Practices among Malaysian Youth: The Moderating Roles of Financial Education. The Journal of Asian Finance, Economics, and Business, 7(6), 525-535.

Bakkeri, A., \& Ali, A. B. (2020). PROFITABILITY OF ISLAMIC BANKS: A PANEL DATA ANALYSIS. Indian Journal of Finance and Banking, 4(3), 26-38. https://doi.org/10.46281/ijfb.v4i3.811

Bashir, M. S., \& Mail, N. H. H. (2011). Consumer perceptions of Islamic insurance companies in Brunei Darussalam, International Journal of Emerging Sciences, 1(3), 285-307.

Dillon, W. R. \& Goldstein, M. (1984). Multivariate Analysis: Methods and Applications, John Wiley \& Sons, New York.

Divanna, J. (2009). A new wave in Banking: Islamic Finance, The Banker, available at: http://ec2-54-72-50-240.eu-west-1.compute.amazonaws.com/Markets/Islamic-

Finance/A-new-wave-in-banking (accessed 6 June 2019).

Fauzi, P. N. F. N. M., Abd Rashid, K., Sharkawi, A. A., Hasan, S. F., Aripin, S., \& Arifin, M. A. (2016). Takaful: A review on performance, issues and challenges in Malaysia, Journal of Scientific Research and Development, 3(4), 71-76.

Field, A. (2000). Discovering Statistics using SPSS for Windows, Sage Publications Ltd, 


\section{London.}

Fiennes, T. (2007). Supervisory implications of Islamic banking: A supervisor's perspective, in Archer S. and Karim R. A. A. (Ed.), Islamic finance: the regulatory challenge, John Wiley \& Sons (Asia) Pte. Ltd., Singapore, 247-256.

Hasan, Z. (2015). Risk sharing versus risk transfer in Islamic Finance: A critical appraisal, ISRA International Journal of Islamic Finance, 7(1), 7-24.

Haseeb, M. (2018). Emerging issues in islamic banking \& finance: Challenges and Solutions, Academy of Accounting and Financial Studies Journal, 22, 1-5.

Hatcher, L. (1994). A step-by-step approach to using the SAS $R$ ) system for factor analysis and structural equation modeling, SAS Institute Inc., Cary, NC, USA

Hossain, B. (2014). Poverty reduction during 1971-2013 periods: Success and its recent trends in Bangladesh, Global Journal of Human-Social Science Research, 14(1), 39-47.

Htay, S. N. N. \& Salman, S. A. (2013). Shari'ah and Ethical Issues in the Practice of the Modified Mudharabah Family Takaful Model in Malaysia, International Journal of Trade, Economics and Finance, 4(6), 340.

Iqbal, M., Aḥmad, A., \& Khan, T. (1998). Challenges facing Islamic banking, Islamic Research and Training Institute, Jeddah.

Isa, M. Y., Rahim, A., Khilmy, A., Mohamed Naim, A., \& Wahab, M. Z. (2017). The issues of second layer charging fee in Wakalah Takaful model practices, International Review of Management and Marketing, 7(2), 378-383.

Islam, A. B. M. (2005). Islamic Constitution: Quranic and Sunnatic Perspectives, Professors Publication, Dhaka.

Jaffer, S., Ismail, F., Noor, J., Unwin, L., \& Ajayi, D. (2010). Takaful (Islamic Insurance): Concept, Challenges, and Opportunities. Milliman Research Report.

Kahf, M., \& Khan, T. (1992). Principles of Islamic Financing, Islamic Research and Training Institute and Islamic Development Bank, Jeddah.

Kammer, M. A., Norat, M. M., Pinon, M. M., Prasad, A., Towe, M. C. M. and Zeidane, M. Z. (2015). Islamic finance: Opportunities, challenges, and policy options, IMF SDN No. 15, International Monetary Fund, April.

Khan, I., Rahman, N. N. B. A., Yusoff, M. Y. Z. B. M., \& Nor, M. R. B. M. (2016). History, problems, and prospects of Islamic insurance (Takaful) in Bangladesh, Springer Plus, 5(1), 785-791. 
Khan, M. F. (2007). Setting standards for Shariah application in the Islamic financial industry, Thunderbird International Business Review, 49(3), 285-307.

Khan, T., \& Ahmed, H. (2001). Risk management: an analysis of issues in Islamic financial industry, Islamic Development Bank, Islamic Research and Training Institute, Jeddah.

Lavrakas, P. J. (2008). Encyclopaedia of survey research methods, Sage Publications, Thousand Oaks, CA

Maghrebi, N., \& Mirakhor, A. (2015). Risk Sharing and Shared Prosperity in Islamic Finance, Islamic Economic Studies, 23(2), 85-115.

Mamun, A., Uddin, M. R., \& Islam, M. T. (2017). An Integrated Approach to Islamic Microfinance for Poverty Alleviation in Bangladesh. ÜniversiteparkBülten, 6(1), 32.

Mohammed, E. (2005). Islamic Finance Gears Up, Finance and Development, 42(4), 46.

Naushad, M., Faridi, M. R., \& Faisal, S. (2020). Measuring the Managerial Efficiency of Insurance Companies in Saudi Arabia: A Data Envelopment Analysis Approach. The Journal of Asian Finance, Economics, and Business, 7(6), 297-304.

Nunnaly, J. (1978). Psychometric theory, McGraw-Hill, New York.

Ochieng, G. O. (2013). Challenges in the Adoption of Takaful Insurance in Kenya, Doctoral dissertation, University of Nairobi, Nairobi.

Pallant, J. (2013). SPSS Survival Manual: A Step by Step guide to data analysis using IBM SPSS, McGraw Hill, Berkshire, England.

Pandey, I. M. \& Ongpipattanakul, V. (2015). Agency behavior and corporate restructuring choices during performance decline in an emerging economy." International Journal of Managerial Finance, 11(2), 244-267.

Rahman, A. M. (2018). Voluntary insurance for ensuring risk-free on-the-go banking services in market competition: A proposal for Bangladesh. Journal of Asian Finance, Economics and Business, 5(1), 17-27.

Rahman, A., Ahmad, W. M. W., \& Buang, A. H. (2011). Can a takaful company reinsure with a reinsurance company?" African Journal of Business Management, 5(30), 11768-11778.

Saleh, M. M. (2016). Challenges in takaful application within conventional insurance framework in Nigeria: The imperative for legislative harmonization of regulatory instruments, Doctoral dissertation. Faculty of Law, University of Malaya, Malaysia.

Salman, A., \& Nawaz, H. (2018). Islamic financial system and conventional banking: A comparison, Arab Economic and Business Journal, 13(2), 155-167. 
Sarwar, M. J. (2016). Future Challenge in Islamic Insurance (Takaful) in Bangladesh", Australian Journal of Sustainable Business and Society, 2(1), 69-80.

Sheheli, S. (2012). Improving livelihood of rural women through income generating activities in Bangladesh, Division of Agricultural Economics, Humboldt University, Berlin.

Sundararajan, V., \& Errico, L. (2002). Islamic Financial Institutions and products in the global financial system: Key issues in risk management and challenges ahead, Working Paper No. 02, International Monetary Fund, Washington, D.C.

West, P. W. (2016). Simple random sampling of individual items in the absence of a sampling frame that lists the individuals, New Zealand Journal of Forestry Science, 46(1), 15-21.

\section{Copyrights}

Copyright for this article is retained by the author(s), with first publication rights granted to the journal. This is an open-access article distributed under the terms and conditions of the Creative Commons Attribution license (http://creativecommons.org/licenses/by/4.0/) 